Streete, A. (2017) Elegy, prophecy, and politics: literary responses to the death of Prince Henry Stuart, 1612-1614. Renaissance Studies, 31(1), pp. 87-106. (doi:10.1111/rest.12197)

There may be differences between this version and the published version. You are advised to consult the publisher's version if you wish to cite from it.

This is the peer-reviewed version of the following article: Streete, A. (2017) Elegy, prophecy, and politics: literary responses to the death of Prince Henry Stuart, 1612-1614. Renaissance Studies, 31(1), pp. 87-

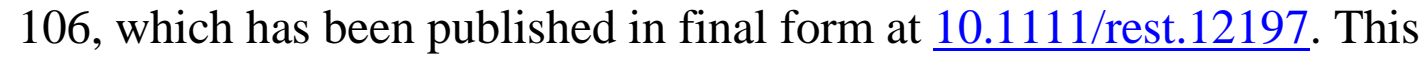
article may be used for non-commercial purposes in accordance with Wiley Terms and Conditions for Self-Archiving.

http://eprints.gla.ac.uk/111241/

Deposited on: 05 April 2016

Enlighten - Research publications by members of the University of Glasgow http://eprints.gla.ac.uk 


\title{
Elegy, prophecy, and politics: literary responses to the death of Prince Henry Stuart, 1612-1614
}

\author{
Adrian Streete
}

On 6 November 1612, James VI and I's eldest son and heir, Prince Henry, died. He was eighteen years old and his death shocked the country. Almost immediately, the political and religious implications of the death were debated. ${ }^{1}$ For a number of years, Henry had been the focus of militant Protestant expectations:

Several works dedicated to him expressed apocalyptic hopes that he might marshal a decisive Protestant victory. There were rumours that after his sister's marriage he planned to go to Germany to fight alongside the Protestant princes. Attempts were being made to mould him into the new Protestant leader on the model of Leicester, Sidney, and Essex. ${ }^{2}$

All the evidence suggests that Henry was personally invested in the aims of militant Protestantism too. ${ }^{3}$ In tandem with his reputation for godliness, antiCatholic rhetoric and ideology found a ready advocate in the prince. As he developed his interests as an art-loving collector, patron, and athlete, increasingly his court was seen in opposition to the king's. ${ }^{4}$ For many in the political nation, the prince was everything that his pacific father was not, particularly in

Research for this article was made possible through the generous support of the Leverhulme Trust and I wish to record my gratitude to that body here. I am also grateful for two very helpful and constructive readers' reports.

${ }^{1}$ For more on these contexts, see the 'Introduction' to Leah Marcus' recent Arden edition of the play: John Webster, The Duchess of Malfi, ed. Leah S. Marcus (London: Bloomsbury, 2009). All references are to this edition.

${ }^{2}$ David Norbrook, Poetry and Politics in the English Renaissance, 2nd edn. (Oxford: Oxford University Press, 2002), 181.

${ }^{3}$ See Roy Strong, Henry, Prince of Wales and England's Lost Renaissance (London: Thames and Hudson, 1986), 52-4, and R. Malcolm Smuts, Court Culture and the Origins of a Royalist Tradition in Early Stuart England (Philadelphia: University of Pennsylvania Press, 1987), 25-31. On Henry and visual culture, see Timothy Wilks, 'The Pike Charged: Henry as Militant Prince', in Timothy Wilks (ed.), Prince Henry Revived: Image and Exemplarity in Early Modern England (Southampton Solent University in association with Paul Holberton Publishing: London, 2007), 180-211; this collection offers a good recent overview of scholarship on Henry.

4 'During the years 1610-12 the division between the prince's and the king's courts was aggravated, owing to the increasing influence of James's new favourite Robert Carr.' Strong, Henry, Prince of Wales, 54. 
his apparent willingness to assert Britain's authority abroad. ${ }^{5}$ In Michael Ullyot's resonant phrase, Henry was, and remained after his death, 'an object of others' interpretative ambitions' ${ }^{6}$

While the promise invested in the prince involved various degrees of projection and wish fulfilment, his death led to a period of uncertainty and transition. We can see this displayed most clearly in the numerous elegies and obsequies that were published in the aftermath of the death and funeral. ${ }^{7}$ These poems were written by figures from across the religious and political spectrum and they contain an intriguing variety of responses. They show that the implications of Henry's death were unstable and contested. In particular, I focus on how elegists use the prophetic mode. As Dennis Kay has authoritatively shown, prophecy is central to elegiac writing in the aftermath of Henry's death. ${ }^{8}$ It allows writers to offer political advice and critique by using the divine sanction of the prophetic voice, advice that in other contexts would probably not be possible. I will argue that this prophetic voice allows a number of political views - sceptical, moderate, and militant - to be expressed. The final part of this essay examines John Webster's elegy for the prince and reconsiders its relationship to his tragedy The Duchess of Malfi (1613/14). I argue that the play's thematic interest in elegy, prophecy, and politics enables Webster to express both militant futility and expectation in the aftermath of Henry's death. The fact that he wrote the elegy at the same time as he was working on the play is significant. ${ }^{9}$ Michael Neill has drawn attention to the 'odd sense that Malfi is in part an extension of Webster's monumentalizing tribute to the hero of English Protestants'. ${ }^{10}$ The last part of the essay develops this suggestion further. It argues that while futility is the dominant mode of the play, like others sympathetic to the militant cause, Webster uses the new heir, Charles, as a focus for apocalyptic expectations.

Nearly all of the elegists reflect upon Henry's martial reputation as proof of his exemplary virtue. Given the reputation that the prince had worked to cultivate, this is hardly a surprise. The elegists are particularly keen to consider how

\footnotetext{
${ }^{5}$ See D. J. B. Trim, 'Calvinist Internationalism and the Shaping of Jacobean Foreign Policy', in Wilks (ed.), Prince Henry Revived, 239-58.

${ }^{6}$ Michael Ullyot, 'James's Reception and Henry's Receptivity: Reading Basilicon Doron After 1603', in Wilks (ed.), Prince Henry Revived, 77. See also Ullyot's PhD thesis “"Venerable Reader, Vulnerable Exemplar”: Prince Henry and the Genres of Exemplarity' (University of Toronto, 2005), especially 84-140.

7 The elegies written for Prince Henry receive their most sustained examination in Chapter Five of Dennis Kay's Melodious Tears: The English Funeral Elegy from Spenser to Milton (Oxford: Clarendon Press, 1990), 124-203. See too Elkin Calhoon Wilson, Prince Henry and English Literature (Ithaca: Cornell University Press), 128-76.

${ }^{8}$ Kay, Melodious Tears, 134-5.

${ }^{9}$ See David Coleman, John Webster, Renaissance Dramatist (Edinburgh: Edinburgh University Press, 2010), $13-16$.

${ }^{10}$ Michael Neill, Issues of Death: Morality and Identity in English Renaissance Tragedy (Oxford: Clarendon Press, 1998), 336-7.
} 
martial valour might now be engaged. In his An Epicede Or Funerall Song, George Chapman remarks that his former patron's mind was 'Preparing for affayres of euery kinde;/ Peace being but a pause to breathe fierce warre'. ${ }^{11}$ Had the prince lived, conflict would have ensued. Yet Chapman's main concern is that the martial energy stirred up by the prince is properly directed:
The President of men; whom (as men can)
All men should imitate, was God and Man.
In these cleere deepes our Prince fish't troubl'd streames
of bloud \& vantage challenge diadems.
In summe, (knot-like) hee was together put,
That no man could dissolue, and so was cut.
But we shal see our foule-mouth'd factions spite
(Markt, witch-like, with one blacke eie, th'other white
Ope, \& oppose against this spotlesse $\operatorname{sun}^{12}$

Though the syntax is typically torturous, Chapman states that Henry's martial instincts were not developed unreflectively, nor were they assumed lightly. In emulating the miles Christi he was obliged to angle in 'troubl'd streames/ of bloud'. But the prince as Gordian knot has now been cut by death. Chapman wonders whether Henry's example is enough to keep his followers from straying from the path of virtue: 'Shall not the rest, that error swalloweth,/ Be, by the Patterne of that Master-peece,/ Help't to instruct their erring faculties?' 13 Even 'the best' might be lost without the prince's physical presence. ${ }^{14}$ Masculine virtue in particular is rendered doubtful: 'Haue thy best workes no better cause t'expresse/ Themselues like men, and thy true Image?' ${ }^{15}$ To fashion oneself in the prince's 'Image' is also to continue his political legacy. The danger is that Henry's followers become 'not thy forms, but Chymaeras brood'. ${ }^{16}$ Such division allows 'foule-mouth'd factions' to mobilize and the 'wild Boare, Barbarisme' to flourish. ${ }^{17}$ Both of these figures have anti-Catholic overtones. Chapman wishes that Henry was still here to make 'blacke Faction blush away her soule'. ${ }^{18}$ While he lived, Roman Catholic power was supposedly held in check. Now, the battles and 'future slaughter' promised by militant ideology against the forces of Roman Catholicism will not be performed. ${ }^{19}$

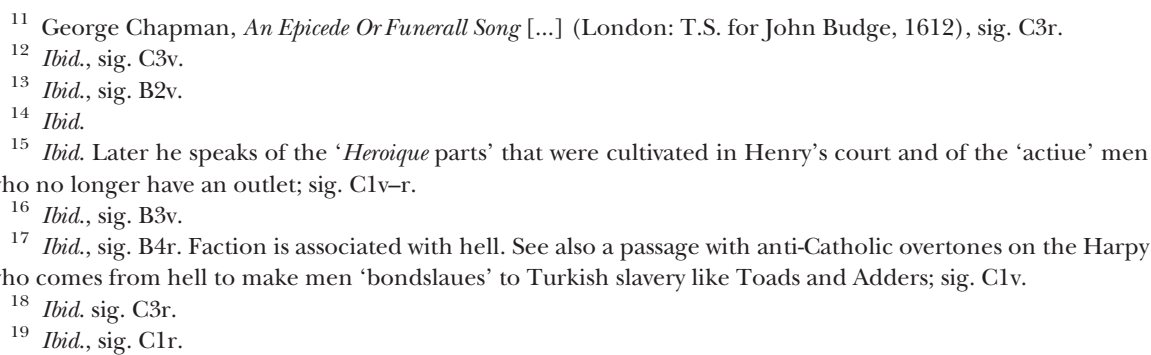


Much of Chapman's elegy considers whether or not it is possible to actively serve the memory of the prince. This is spelled out more fully in this passage:

And tho men now are scarce to warmnesse s[t]ir'd

With loue of thee; but rather colde and dead

To all sense of the grace they forfeited

In thy neglect, and losse; yet after-ages

Would be inflam'd, and put on holy rages

with thy inspiring vertues; cursing those

Whose breaths dare blast thus, in the bud, the Rose.

But thou (woe's me) art blown vp before blowne,

And as the ruines of some famous Towne,

Show here a Temple stood; a Pallace, here;

A Cytadell, an Ampitheater;

Of which (ahlas) some broken Arches, still

(Pillars, or Columns rac't; which Art did fill

With all her riches and Diuinitie)

Returne their great, and worthy memorie:

So of our Princes state, I nought rehearse

But show his ruines, bleeding in my verse. ${ }^{20}$

In the first part of the quotation, Henry's followers are cold, lacking in masculine godly 'grace' and scarcely able to conceive of their loss. In the future the memory of the prince's virtues may well inspire 'holy rages' and a curse on those who opposed the prince in life. Yet in the second half of this quotation the idea of memory becomes rather less facilitative. The image of the blown rose merges with that of the city reduced to ruins, which then in turn memorializes the ruined Henry. ${ }^{21}$ This vision of martial destruction sits uneasily alongside the first half of the verse. How can the prince's 'ruines' and the poet's 'bleeding verse' inspire the kind of 'holy rage' of which the prince presumably would have approved? ${ }^{22}$ Chapman's elegy is caught between the stasis of grief and the motility that memory may inspire at some point in the future. This is why the trope of the ruined city is so central. It is typically associated with the prophetic books of the Old Testament, the idea of translatio imperii, apocalyptic writings against Rome, and godly exhortations, especially the Jeremiad. ${ }^{23}$ Yet Chapman twists the idea around so that the 'ruines' are not those of a

20 Ibid., sig. C4v-r.

21 The 'blown rose' may recall Shakespeare's Cleopatra at III.xiii.38. Antony and Cleopatra in The Norton Shakespeare, ed. Stephen Greenblatt et al. (New York and London: W. W. Norton and Co., 1997).

22 As Andrea Brady has observed, 'Rituals and elegies can be understood to express both collective values abstracted from the memory of the dead and the individuality of emotional responses.' English Funerary Elegy in the Seventeenth Century: Laws in Mourning (Basingstoke: Palgrave Macmillan, 2006), 3.

23 For a text that uses most of these modes, see Jan Baptista van der Noot (and Edmund Spenser), A Theatre Wherein be represented as wel the miseries and calamities that follow the voluptuous Worldlings (London: Henry Bynneman, 1569). On the Jeremiad, see Mary Morrissey, Politics and the Paul's Cross Sermons, 1558-1642 (Oxford: Oxford University Press, 2011), 183. 
vanquished external enemy but of the 'Princes state'. Militant Protestant action will surely come in the future, inspired by Henry's memory. But in the present period of emotional grief, Chapman prefers to focus on the bleeding 'ruines' of the prince's corpse, an image that stands as a synecdoche for the cities that the prince might have conquered had he lived. As Ullyot notes, 'Elegy forces poets to approximate their occasional representations to the truth, to temper their hyperbole with the experience of failure. ${ }^{24}$ Given this limitation, it is not surprising that the poem ends with a speech by the prince on his deathbed praising King James - 'in a feastfull Peace your Empire kept' - one that urges him to continue his pacific policy. ${ }^{25}$

A surprisingly large number of writers follow in Chapman's politically cautious footsteps. Although most spend more time that he does in lauding Henry's militarism, this does not preclude some fairly strong critiques of this ideology and those who would try to appropriate it. Thomas Campion finds no necessary contradiction between Bellona and Eirene. He says: 'How fit for peace hee, and rosie bells? / How fit to stand in troopes of iron heads? ${ }^{26}$ Only Henry, it seems, is able to square this circle:

This feare euen like a commet that hangs high,

And shootes his threatening flashes through the skye,

Held all the eyes of Christendome intent

Vpon his youthfull hopes, casting th'euent

Of what was in his power, not in his will:

For that was close conceal'd, and must lye still

As deeply hid, as that design which late

With the French Lyon dyed. ${ }^{27}$

The comet here is a portent of the end, not the end itself. Predictions about what the prince may or may not have done litter the literary landscape as writers try to shape his legacy to various ends. There is clearly a degree of elegiac wishfulfilment in many of these forecasts. For Campion, the test-case is the prince's namesake and mentor, Henri IV of France. Predictions of what both men might have achieved are at best futile and, at worst, dangerous. ${ }^{28}$ Just as man should not delve too deeply into the mysteries of divine power, so the military promise exemplified in the prince is now halted. This could even be called an anti-prophetic strategy.

In his Two Elegies, the Spenserian poet Christopher Brooke says of Henry that 'Bellona was his GODDESSE, whom he sought/ With knightly valour, more

\footnotetext{
${ }^{24}$ Michael Ullyot, 'The Fall of Troynovant: Exemplarity after the Death of Henry, Prince of Wales', in Alan Shepard and Stephen D. Powell (eds.), Fantasies of Troy: Classical Tales and the Social Imaginary in Medieval and Early Modern Europe (Toronto: CRRS Publications, 2004), 285.

${ }^{25}$ Chapman, An Epicede, sig. E1r.

26 Thomas Campion and John Coperario, Songs of Mourning [...] (London: Iohn Browne, 1613), sig. B1v.

27 Ibid., sig. B1v.

28 See Strong, Henry, Prince of Wales, 72.
} 
than courtly grace'. ${ }^{29}$ The poem glorifies the prince's military prowess. However, he also wonders about what might follow in the wake of the death. Affect is seen as 'mortall', passions are now 'drearie', and pity is overcome by 'Feares' ${ }^{30}$ The elegist praises action but knows that it is forestalled by grief. He addresses fellow elegists, former members of the prince's court, and soldiers:

And yee the Noblest estate of men
(Soldiers) embast in these degenerate times;
Though ye afford most matter to my Pen
T'excite your Teares; yet least my harsher Rimes
On your sad cause, doe make you mad agen,
Rest to your Passion: Harke the Churches Chimes -
Ring to GODS service; serue him then in Peace,
Wax poore in spirit, and let action cease.

All that is left is lachrymal self-dissolution. One consolation is religion and the pacific policy of the monarch. In this period of trauma, soldiers should retreat from action, lament, and pursue peace. As Henry Burton notes, some may have expected that the 'Heroick Chieftan' would have 'Tam'd the Barbarian, and wilde Indian'. But instead 'dastard Death hath founded his Alarmes, / Bidding vs rest in rust, and leaue our Armes' ${ }^{32}$ Henry's followers must resign themselves to the workings of providence. Furor, military and literary, is no longer possible.

Burton's elegy was printed in Joshua Sylvester's compendium Lacrimae Lachrymarum. This volume's 1613 edition also includes verses by poets such as Hugh Holland, Henry Cornwallis, Sir Edward Herbert, Sir Henry Goodyear, Sir William Sidney, and John Donne. It is not that the collection is without the odd burst of militant Protestant sabre rattling. Holland, for instance, writes that Henry was one 'that should heaw downe the Turkes like Cattle'. And this poet also gets a quick shot across Spanish bows, noting that the prince's 'Toombe should be another new Escurial ${ }^{33}$ But the overall tone of the collection is much more in keeping with Burton in its caution and moderation. Even

\footnotetext{
${ }^{29}$ Christopher Brooke, Two Elegies [...] (London: T.S. for Richard More, 1613), sig. C1v. On Brooke and the Jacobean Spenserians, see Michelle O'Callaghan, The 'Shepheards Nation': Jacobean Spenserians and Early Stuart Political Culture, 1612-1625 (Oxford: Clarendon Press, 2000), 63-85.

${ }^{30}$ Brooke, Two Elegies, sigs. B1r-B2v. On the early modern passions, see Susan James, Passion and Action: The Emotions in Seventeenth-Century Philosophy (Oxford: Oxford University Press, 1997), Gail Kern Paster, Humoring the Body: Emotions and the Shakespearean Stage (Chicago and London: The University of Chicago Press, 2004), Gail Kern Paster, Katherine Rowe, and Mary Floyd-Wilson (eds.), Reading the Early Modern Passions: Essays in the Cultural History of Emotion (Pennsylvania: University of Pennsylvania Press, 2004) and Christopher Tilmouth, Passion's Triumph Over Reason: A History of the Moral Imagination from Spenser to Rochester (Oxford: Oxford University Press, 2007).

31 Ibid., sig. C4v.

32 Henry Burton, A Pilgrims Sad Obseruation, in Joshua Sylvester, Lacrimae Lachrymarum and Syndry Funeral Elegies (London: Humfrey Lownes, 1613), sig. G4v.

${ }^{33}$ Hugh Holland, On the Untimely Death, in Ibid., sig. D4v.
} 
Sir William Sidney seems reluctant to assign the militaristic mantle associated with his family to 'glorious Henry', noting:

\author{
ARCADIANS knowe no Other, for APOLLO, \\ No other MARS (in Armes or Arts to followe \\ As DEMI-GODS, as well of Warre as Witt) \\ Then Sidneys yerst, or SEMI-SIDNEYS, yet. ${ }^{34}$
}

Henry may have fitted the militant Protestant bill while he was alive. But, these lines suggest, the true political heir of Sidney is still to emerge. Since the 1570s, English militant Protestant ideology had identified a series of figureheads as the promised hero who would lead the nation into battle against the Catholic antichrist on the continent. However, even the most vociferous adherents of this view had to acknowledge the various limitations, political, personal, or physical, of those individuals. ${ }^{35}$ Militant Protestantism is always caught between lauding the heroes of the past, coming to terms with their limitations, encouraging present heroes to further action, and identifying the standard bearers of the future. In a number of the elegies for Henry, it seems that memory is all that is left. The exuberant energia associated with genres like panegyric is actively foreclosed in the turn to the elegiac mode. ${ }^{36}$

John Donne is similarly cautious. He writes that the prince's 'reputation was an ecstasy/ On neighbour States, which knew not why to wake/ Till he discovered what ways he would take' (26-28). ${ }^{37}$ The tone here is circumspect: Henry's 'reputation' might have disconcerted those overseas waiting to see how he would have proceeded. Yet the prince, Donne implies, did not yet know himself what he would do. The verse continues in this conditional mode: 'Was his great father's greatest instrument,/ And activest spirit, to convey and tie/ This soul of peace, through christianity?' (32-34) Whether we read this line as an exclamation or as a question, the only sensible response, Donne implies, is: who knows? The project of Jacobean irenicism might be praiseworthy but it is far from being universally secure. The poem goes on to say: 'Was it not well believed, that he would make/ This general peace' and that 'his times might have stretched out so far/ As to touch those, of which they emblems are?' (35-38) Once more the conditional construction undermines the laudable sentiments expressed here. The reason that Donne refuses to directly affirm Henry's pacific credentials is similar to that of Thomas Campion: mere belief in the promise of what a prince might do (or have done) is really no belief at all. Donne grants that in Henry's 'last days [...] we saw heaven did allow/ That, but

\footnotetext{
${ }^{34}$ Sir William Sidney, An Elegie and Epistle, in Ibid., sig. H1r.

35 See Blair Worden, The Sound of Virtue: Philip Sidney's Arcadia and Elizabethan Politics (New Haven and London: Yale University Press, 1996), 71-124, and Jason White, Militant Protestantism and British Identity, 1603-1642 (London: Pickering and Chatto, 2012).

${ }^{36}$ See Ullyot, 'The Fall of Troynovant', 272-3.

37 John Donne, Elegy upon the untimely death of the incomparable Prince Henry, in John Donne: The Complete English Poems, ed. A. J. Smith (Harmondsworth: Penguin, 1976), 254.
} 
from his aspect and exercise,/ In peaceful times, rumours of war did rise'.' Yet 'now this faith is heresy' and 'we must/ Still stay' (40-44). The proponents of militarism have, according to this view, been muted.

There is more to Donne's message. Fascinatingly, this last quoted lines draws upon Matthew 24, one of the most prophetic (and apocalyptic) verses in the Gospels. Christ sits with his disciples on the Mount of Olives and they ask him 'what sign shall be of thy comming [sic], and of the end of the world' (Matthew 24: 3). ${ }^{38}$ He first warns them to 'Take heede that no man deceiue you' since 'many shall come in my Name, saying, I am Christ, and shall deceiue many.' He then says that 'ye shall heare of warres, and rumours of warres: see that ye be not troubled: for all these things must come to passe, but the end is not yet' (Matthew 24: 4-6). We can read Donne's allusion to this verse in two ways. Conventionally it might affirm Christ's message and counsel his readers not to worry about militaristic posturing. Alternatively, given the apocalyptic context and Christ's warning not to be deceived by those who claim to come in his name, we can also see an implicit criticism both of militant Protestantism and of the prince for indulging the fantasies of those who invested so much in his promise. As Christ says later in Matthew 24, the apocalypse will come, and when it does, mankind will see the 'abomination of desolation' (Matthew 24: 15) spoken of by Daniel and the other Old Testament prophets, one that will 'deceiue the very elect' (Matthew 24: 24). Because the prelude to the apocalypse will cause confusion and deception of the godly, those living before the end need to be doubly sure that they are not seduced by false prophets. To be deceived in this way is dangerous politics and bad typology. At present, Donne writes, God has 'spent his store/ Of plagues, on us' and now 'when more/ Would ease us much, doth he grudge us misery' (45-47). Final punishment is deferred. Prince Henry is no second Christ. The use of Matthew 24 explains why some Protestants might have thought that he was. But Donne's skilful allusion to this scriptural verse refuses to let them off the political hook for this belief.

Donne's sceptical use of this particular biblical mode brings us to those writers closer to the militant end of the spectrum. Many of these elegists are, unsurprisingly, more willing to invoke prophecy and apocalypse directly. They are also more likely to offer explicit political advice. ${ }^{39}$ A good example is Henry Peacham, who mourns the fact that 'Britaine, warlike Arthur lost' and notes the 'terror' that the Ottoman Empire, Spain, Rome, and France supposedly felt when considering the prince. ${ }^{40}$ Still, this is no mere militant panegyric. Peacham reflects interestingly on a central tension in Protestant praise of the prince, one that is implicit in a number of the poems quoted above. As he bluntly puts it: 'Yet all are Adams earthly weake,/ Adord like Idols till they

\footnotetext{
38 All biblical references are to the Geneva Bible. The Bible, That Is, The Holy Scriptures [...] (London: Christopher Barker, 1599).

${ }^{39}$ See Alexandra Walsham, Providence in Early Modern England (Cambridge: Cambridge University Press, 1999), 167-8; 203-18.

${ }^{40}$ Henry Peacham, The Period of Mourning [...] (T.S. for Iohn Helme, 1613), sig. C4r; D1v.
} 
breake'. ${ }^{41}$ Instead of pointing to the gap between what Henry did and what he might have done, Peacham notes the idolatrous implications of placing too much political and spiritual promise in mere flesh. He says: 'That what Rome of her Titus said/ May to late Henry be applied;/ That he for his own good is gone. ${ }^{42}$ For all that Henry brings to mind worthy classical exemplars like Titus, to oppose modern, idolatrous Rome with one who is idolized by some like a latter-day emperor is, to put it mildly, a contradiction in terms.

For many of these prophetically inspired elegists, Henry's death acts as a call to repentance. Robert Allyne's Funerall Elegies rails against 'Antichristian Rome' and predicts that, had the prince lived, James would have maintained peace at home while his son vanquished 'proud Babell, and her champion Spaine' abroad. ${ }^{43}$ Here prophecy is fused with apocalyptic typology. Now, however, is a time for 'true repentaunce' and the hope that God might 'restore/ This darkened Iland to her former gloire' in the person of 'our tender Prince', James. ${ }^{44}$ The suggestion that the king adopt a more militant policy goes hand in hand with the inference that he might not be quite up to the task. As examples like this show, the death of Henry gave those who were critical of the king's policy of peace, especially with Spain, an opportunity to vent their frustrations with the state. John Davies' The Muses Teares says that the perfection embodied by the prince will not 'returne till GOD in Flesh returne', a more positive reading of Henry's eschatological significance. Davies has few doubts that the prince 'would haue thundred lowd, in War'. ${ }^{45}$ But he also has a warning for the king:

For, such as wilbe Sheepe, the Wolfe deuoures:

Then, sheepish Kings must flee all Beasts of prey,

Or keepe Presumption downe in subiect Pow'res,

Lest long conniuence make it long for sway. ${ }^{46}$

Drawing on John 10: 12, Davies argues that an overly pacific ideology is likely to weaken the state by opening it up to external threat and internal dissention. ${ }^{47}$ For the king to adopt a more militaristic stance is, in Davies' view, a question of political pragmatism. Unlike Chapman, for example, he believes that the energy of the militants will be expressed sooner rather than later.

One of the most outspoken elegies to emerge in this line is Prince Henries Obsequies by George Wither. As Michelle O' Callaghan has noted, Wither is part of the same group of Jacobean Spenserians as Brooke. This group often draw

41 Ibid., sig. D1r.

42 Ibid., sig. D2v.

43 Robert Allyne, Fvnerall Elegies [...] (London: T.P. for Iohn Budge, 1613), np.

44 Ibid., np.

${ }^{45}$ John Davies, The Mvses-Teares [...] (London: G. Eld for Iohn Wright, 1613), sig. A2r.

46 Ibid., sig. Blv.

47 The verse reads as follows: 'But an hireling, and hee which is not the shepheard, neither the sheep are his owne, seeth the wolfe coming, and hee leaueth the sheepe, and fleeth, and the wolfe catcheth them, and scatereth the sheepe.' (John 10: 12). 
on allegorical modes found in Spenser's great epic The Faerie Queene and 'employed in the denunciation of Spanish popery and criticisms of the Jacobean peace'. ${ }^{48}$ Although there are a number of self-consciously Spenserian elegies written for the prince, there is little evidence of Spenserian allegory in Wither's Obsequies. ${ }^{49}$ Dedicated to Robert Sidney, Earl of Leicester, the collection mourns instead the ineffectiveness of pastoral allegory in the aftermath of Henry's death:

Thrise happy had I bene, if I had kept

Within the circuit of some little village, In ignorance of Courts and Princes slept,

Mourning of an honest halfe-plough tillage:

Or else I would I were as young agen,

As when Eliza our last Phoenix dide ${ }^{50}$

Nostalgia for Elizabethan rule is fused with a general criticism of the present court. But it does not take Wither long to take aim at more specific targets. In the words of Kay, the poet 'strengthens the religious and political implications of such stock machinery that the other Spenserians had already begun to exploit' ${ }^{51}$ Despite the fact that the collection contains poems dedicated to all members of the royal family, in Elegy 7 the poet makes it clear who the political nation should now focus upon: 'Rome although thou threat'st/ He's like enough for to be Charles the great'st. ${ }^{52}$ Though Henry promised military action and success, 'now I see/ they are ordain'd to be anothers taske'. The prophetic promise of the end times is not arrested, merely deferred. But whereas Donne saw this as a chance to criticise militant ideology, for Wither it informs his eschatological reading of history. Another 'of the Stewards line' will 'aduance beyond the Alpes by plumed caske' to defeat Britain's enemies. ${ }^{53}$ Fantasies of future militant advancement into the European continent are framed in a prophetic voice that is a central part of Wither's poetic persona, one that offers a way past the foreclosure of genre so often found in these elegies.

Yet Wither is no idolizer of princes. In Elegy 15, he uses a reflection on Henry's lost promise to state: 'Trust not (saith Dauid) trust not in a Prince./ Yet we hope't lesse, in God Ile sweare we did,/ In iealousie he therefore tooke him hence'. 54 The country is at fault for having put too many hopes in the prince. He also notes that Henry 'almost made this Ile to Idolatrize'. ${ }^{5}$ Is the

48 O' Callaghan, The 'Shepheards Nation', 14.

49 See Kay, Melodious Tears, 162-3.

${ }^{50}$ George Wither, Prince Henries Obsequies [...] (London: Ed. Alde for Arthur Iohnson, 1612), sig. B2v.

51 Ibid., 175. See also Norbrook, Poetry and Politics, 215-20, and O' Callaghan, The 'Shepheards Nation', 147-87.

${ }^{52}$ Wither, Prince Henries Obsequies, sig. B2v.

53 Ibid., sig. D1v.

54 Ibid., sig. C2v.

55 Ibid., sig. D4v. Henry's elaborate funeral, something that many of the elegists praise, is also rebuked: 'What needed all that Ceremonious show?', sig. D3v. 
conditional 'almost' enough to convince the reader that the poet fully believes this sentiment himself? Probably not. Like the Old Testament Jews, England has been punished by a jealous God for having idolized the prince:

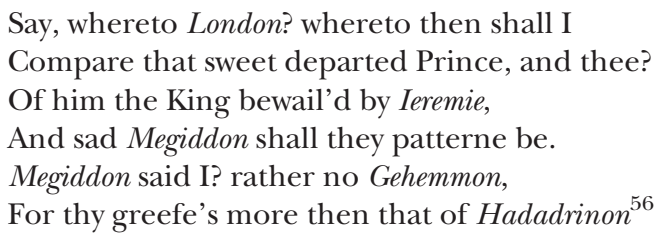

This verse alludes to the book of Jeremiah, most of which takes place in the aftermath of Josiah's death which the 'King bewail'd'. Josiah, King of Judah, is one of the godliest monarchs in the Bible and in the early modern period was best known for his reforming zeal and sanctions against idolatry. Reformist Protestant figures like Edward VI and Prince Henry were commonly associated with Josiah. ${ }^{57}$ However, as Wither's verse makes clear, after the king's death at Megiddo the Jews rejected his religious reforms and once more fell back into idolatry. Much of the book of Jeremiah is an account of the prophet's attempts to persuade the Jews of their folly, and pointing out the apocalyptic consequences of failing to do so. Wither's reference to 'Gehemmon' is significant since it is a site also singled out by Jeremiah for particular comment. As noted in Chapter Nineteen, the prophet is sent here by God to preach to the Jews and to warn them of the impending destruction of Jerusalem: 'Because they haue forsaken me, and prophaned this place, and haue burnt incense in it vnto other gods, whom neither they, nor their fathers haue knowen, nor the Kings of Iudah (they haue filled this places also with the blood of innocents)' (Jeremiah 19: 4). The idolatry, sacrifice, and false religion of the recalcitrant Jews of the Old Testament is, for hotter early modern Protestants like Wither, a warning against the dangers of a Roman Catholic fifth column. Sure enough, his collection is littered with predictable references to 'Romes damned fiends' and 'the wicked Whore of Rome' 58

The book of Jeremiah also offers a stark warning about the consequences of the Jews' failure to develop a coherent and robust national identity. Chapter Five contains the following grim warning: 'Loe, I will bring a nation vpon you from farre, $\mathrm{O}$ house of Israel, saith the Lord, which is a mightie nation, and an ancient nation, a nation whose language thou knowest not, neither vnderstandest what they say' (Jeremiah 5: 15). Because the Jews have 'serued strange gods in your land, so shall yee serue strangers in a land that is not yours' (Jeremiah 5: 19). Such well-known verses inform Wither's use of the Jeremiad and its

\footnotetext{
56 Ibid., sig. C3r.

${ }^{57}$ See Kay, Melodious Tears, 133-5, and on Edward and Josiah see Diarmaid MacCulloch, Tudor Church Militant: Edward VI and the Protestant Reformation (London: Penguin, 2001), 57-104.

${ }^{58}$ Wither, Prince Henries Obsequies, sigs. D2v and E2v.
} 
prophetic voice. Indeed, they sanction the bold political critique found in the concluding elegies of the collection. According to Wither, the Protestant identity of the state can only be protected if it is properly shored up at home. In the aftermath of Henry's death:

[...] more Romes Locusts doe begin to swarme, their courage now with stronger Hopes they arme,

And taking hold of this thy Trans-migration,

They plot again to sue for tolleration $[\mathrm{sic}] .^{59}$

Those arguing for religious toleration should be resisted. In fact, toleration is a kind of arming against the state. This view sees popish militancy and the prospect of invasion advanced in every concession made. The focus of Wither's political prophesying is not on the king who, although carefully praised, ${ }^{60}$ is clearly viewed sceptically. The poet turns again to the new heir:

Then Charles take heede, for thou shalt heare a-far

Some cry peace, peace, that haue their hearts on warre.

Let Policie Religion obey,

But let not Policie, Religion sway:

Shut from thy counsells [sic] such as haue profest

The worship of that Antichristian beast. ${ }^{61}$

Religious concerns are secondary to the political considerations that should drive Charles' actions. Moreover, the verse could be read as warning the prince away from the powerful Howard faction at court, many of whom were sympathetic to Roman Catholicism. ${ }^{62}$ This reading is supported by the suggestion that Charles should 'Banish all Romish Statists, do not suppe,/ Of that pidepainted Drabbs infectious Cuppe'. ${ }^{63}$ He should also

[...] suruey e'ne thine owne family:

That at thy table none partaker be,

That will not at Christs boord partake with thee:

The Lords great day is neere, tis neere at hand,

Vnto thy combat see thou brauely stand. ${ }^{64}$

59 Ibid., sig. E1v.

${ }^{60}$ For praise of James see sig. D3r.

${ }^{61}$ Ibid., sig. E2r. On the expectations placed on Charles as new heir, see Ullyot, 'Venerable Reader, Vulnerable Exemplar', 136-40.

${ }^{62}$ After Henry's death, efforts were made to protect Charles from Roman Catholic influence and he was assigned two Protestant divines, including George Hakewill, to instruct him in Protestant doctrine. See Mary Anne Everett Green (ed.), Calendar of State Papers, Domestic [...] 1611-1618, (London: Longman, Brown, Green, Longmans and Roberts, 1858), 160.

${ }^{63}$ Wither, Prince Henries Obsequies, sig. E3v.

64 Ibid., sig. E3v. 
A general purging of the court is required. This not-so-coded warning against James' indulgence of papists and Anne's Roman Catholicism is the boldest example of Wither's prophetic politicking in this text. Fusing prophecy with apocalyptic projection, the elegist ends with the message that only through anti-Catholic 'combat' at home might Protestant statehood be protected and advanced.

III

The final elegy that I want to examine is written by a man much better known for his theatrical achievements. John Webster's elegy A Monvumental Columne is one of his lesser-studied works. It is much closer to Wither's religious and political concerns than it is to Chapman's. ${ }^{65}$ The poem is dedicated to the king's favourite Robert Carr. This is a notable if complicated move on Webster's part. Though Carr had previously been sympathetic to the aims of the militant Protestants, 1612-13 saw those sympathies shifting. There was also no love lost between Prince Henry and Carr. ${ }^{66}$ Carr had supported a French match for the prince much to Henry's distaste. ${ }^{67}$ Perhaps Webster was unaware of these facts. Maybe his claim that, when it comes to Henry's memory, nothing other than the 'preservation of His Fame' could be 'dearer' to Carr is simply the hyperbole of a writer seeking a powerful, well-connected patron. ${ }^{68}$ Yet, as we have seen, the elegies for Henry's death show how acutely aware their writers are of the contemporary political terrain. I think it unlikely that Webster was ignorant of the contexts within which his dedication might have been read. He does not claim that his poem shall revivify the prince. But he does promise that the moment of death will be anatomized: 'you shall perceive him draw a little breath, such as gives us comfort His Criticall day is past, and the glory of new life risen neither subject to Physicke, nor Fortune. ${ }^{69}$ Although it uses a conventional vanitas trope linking death with resurrection, the line also plays on the eschatological promise of Henry's rebirth. The certainty of the prince's resurrection affirms the militant and apocalyptic Protestant ideology that he supported and whose fortunes are now uncertain. Perhaps the dedication to Carr

\footnotetext{
${ }^{65}$ See Kay Melodious Tears, 165, and Neill, Issues of Death, 335-8. See too David Gunby's 'Introduction' to the text in David Gunby, David Carnegie, and MacDonald P. Jackson (eds.), The Works of John Webster: An Old-Spelling Critical Edition, Vol. 3 (Cambridge: Cambridge University Press, 2007), 360-69, and Kate Aughterson, "Roaring Boys and Weeping Men”: Radical Masculinity in Webster's The Duchess of Malf', in Deborah Philips and Katy Shaw (eds.), Literary Politics: The Politics of Literature and the Literature of Politics (Basingstoke: Palgrave Macmillan, 2013), 45-63.

${ }^{66}$ See Alasdair Bellany, The Politics of Court Scandal in Early Modern England: News Culture and the Overbury Affair, 1603-1660 (Cambridge: Cambridge University Press, 2002).

${ }^{67}$ See Robert B. Bennett, “John Webster's Strange Dedication:' An Inquiry into Literary Patronage and Jacobean Court Intrigue', English Literary Renaissance 7 (1977), 362. I agree with Bennett's argument that Webster's dedication to Carr is insincere and that the elegy contains subtle criticisms of Carr's policy.

${ }^{68}$ John Webster, A Monvmental Colvmne [...] in The Complete Works of John Webster, Vol. 3, ed. F.L Lucas (London: Chatto and Windus, 1927), 273.

69 Ibid.
} 
is a reminder to him not to forgo the political and religious legacy of the prince? Indeed, the poem begins in a defiantly eschatological vein:

The greatest of the Kingly race is gone,

Yet with so great a reputation,

Layd in the earth, we cannot say hee's dead,

But as a perfect Diamond set in lead,

(Scorning our foyle) his glories do break forth,

Worne by his Maker, who best knew his worth:

Yet to our fleshly eyes, there does belong

That which we thinke helps griefe, a passionat $\left[\right.$ sic] tongue. ${ }^{70}$

Death is not the end but rather the beginning of the 'glories' embodied by the prince. He is able to 'break forth' and transcend the flesh that his surviving followers (and their verses) must be clothed in through sheer force of 'reputation'. The phrase 'break forth' echoes Isaiah 54: 1: 'Reioyce, O barren that diddest not beare: breake forth into ioy and reioyce, thou that didest not trauaile with child: for the desolate hath moe children then the married wife, sayeth the Lord.' Even though the prince has died childless - indeed, was little more than a child himself - this does not necessarily mean that the promise embodied by him is extinguished. As the biblical chapter goes on to note, those who presently find themselves 'desolate' shall not be 'confounded' (Isaiah 54: 4) since 'For a little while haue I forsaken thee, but with great compassion will I gather thee' (Isaiah 54: 7). The enemies who oppose God's chosen 'shall fall' (Isaiah 54: 15). The marginal notes in the Protestant Geneva Bible explain that this section of Isaiah can be read as an allegory of an afflicted and captive Church being saved from the clutches of its enemies by Christ. ${ }^{71}$ Its use in the poem thus represents another allusion to an eschatological narrative where the truth may be occluded yet, in time, is eventually revealed in glory. In Webster's verse, Prince Henry is not so much a resurrected hero as the typological exemplar of a much larger apocalyptic unveiling that cannot be halted by something as petty as mere physical death.

Turning to Henry's military promise, Webster notes that 'by day Mars held his launce' and that 'men thought his star/Had markt him for a just and glorious war'. ${ }^{72}$ The thought of what might have been haunts this elegy too. Such lines speak to what Kate Aughterson has rightly called the 'classical tradition of masculine virtue' associated with Henry. ${ }^{73}$ Significantly, though, the most extended discussions of military matters takes place not in relation to Henry but in a section devoted to Edward Plantagenet, the Black Prince. Kay calls this

\footnotetext{
${ }^{70}$ Ibid., 1-8.

71 The Geneva Bible commentary also associates this process with the ministry, death and resurrection of Christ; notes to Isaiah 54.

72 Webster, A Monvmental Colvmne, 56, 64-5.

73 Aughterson, 'Roaring Boys', 46.
} 
passage a commonplace digression. However, I think that to leave it there is to miss the significance of Webster's reference. ${ }^{74}$ The Black Prince was probably best known in early modern England for his victories against the French. These were achieved during the thirteenth century when the national identities of both countries were beginning to be decoupled from one another as England struggled to establish her political and military distinctiveness. Webster writes that Edward 'shook to th' Center the whole Realm of France, / That of warm bloud open'd so many sluices,/ To gather and bring thence sixe Flower de Luces' ${ }^{75}$ The rhyme is risible, but the political message is not. In 1613 and 1614, the most likely candidate for marriage to Prince Charles was France. The following contemporary account gives a good sense of what was at stake:

The Prince's death taking away hopes of supply by his marriage, a Parliament is talked of for February; there is much canvassing for vacant offices [...] The Princess's marriage postponed, lest Ambassadors coming to condole for the Prince should find feasting and dancing. The Prince's debts are 90001, but his property is worth much more; his medals and coins worth 30001. His papers show that he had many vast conceits and projects. A mad youth rushed into St James's naked, pretending to be the ghost of the late Prince. Lewis Bayley, one of his chaplains, is called to account for preaching on the decay of religion, owing to Popery in the Council. The King declares zeal for religion. ${ }^{76}$

Since the failure of James and Robert Cecil's 'Great Contract' in 1610, a plan which would have seen the king granted annual subsidies by the Commons, Parliament had not sat. ${ }^{77}$ Yet the problem of supply to the royal coffers had not gone away. The king found himself caught in that typical Stuart no-man's land between those who believed he could obtain the necessary finances without recourse to Parliament and those for whom the recall of Parliament was imperative. The marriages of James' surviving children, Elizabeth and Charles, were also central to this problem. Elizabeth was betrothed in 1613 to Frederick, Count Palatine and an Elector of the Holy Roman Empire. The marriage not only brought James into alliance with a key Protestant partner on the European continent. It also brought significant financial benefits. If the king could pair his surviving son off with a similarly wealthy Roman Catholic wife then both his political scruples and coffers might be satisfied.

Nevertheless, there was considerable opposition to any Roman Catholic match at court. Small wonder that the king felt obliged to profess his 'zeal'. The

\footnotetext{
${ }^{74}$ Kay, Melodious Tears, 165.

75 Webster, A Monvmental Colvmne, 71-73.

76 Green (ed.) Calendar of State Papers, Domestic, 156.

77 This account draws upon Samuel R. Gardiner, History of England from the Accession of James I to the Outbreak of the Civil War, 1603-1642, vol. II 1607-1616 (London: Longmans, Green and Co., 1883), 166-258; David Lindley, The Trials of Frances Howard: Fact and Fiction at the Court of King James (London and New York: Routledge, 1993), 77-122; Bellany, The Politics of Court Scandal, 29-38.
} 
sermon referred to above by Lewis Bayley, one of Prince Henry's chaplains, was especially controversial. Bayley claimed that Henry had told him that 'religion lay a-bleeding, and no marvel ... when divers Councillors hear Mass in the morning, and then go to a court sermon and so to the Council, and then tell their wives what passes, and they carry it to their Jesuits and confessors. ${ }^{78}$ Rumours of a popish fifth column, never far from the surface in seventeenthcentury England, were rife. In a sermon printed in 1614, Thomas Adams quoted Ezekiel 13: 10-18 and concluded: 'This is shamefull in a Preacher, to winke at Idolatrie in Bethel, because he is in the Kings Chappell. ${ }^{79}$ As with the elegies, the integration of the prophetic mode with political commentary is a key feature of many sermons preached at this time. A little later, Adams offers a stout defence of the right to preach in the politically prophetic mode:

Threaten your Priests no longer with suites and quereles, and expulsions, from their poore Vineyards, which you haue robbed, because they bring you sowre grapes, sharpe wine of reproofs [...] Barre not the freedome of their tongues, by tying them to conditions, this you shall say, and this not say, on pain of my displeasure. (You may preach against sinnes, but not meddle with the Pope; or you may inueigh against Rome \& Idolatrie, so you touch not at my Herodiae, or you may taxe Lust, so you let mee alone for Nabaoths Vineyard.) ${ }^{80}$

The veiled critique of James's policies and of Anne of Denmark is striking. ${ }^{81}$ Another preacher, Thomas Scott, railed in a sermon preached at court about 'Italian Courtship or Craft' and warned his auditors to 'beware of them, that do acknowledge England to be their country, but will haue Rome to be the randououe [sic] and rule of their religion'. ${ }^{82}$ To decry false religion is also to assert a patriotic conception of Protestant Englishness in the face of subtle Roman Catholic subversion. For his pains, Scott was examined by the Privy Council and by the Earl of Northampton, the powerful head of the Howard faction. ${ }^{83}$ In Peter McCullough's words, 'There was plenty in Scott's sermon to anger an already defensive Henry Howard. ${ }^{84}$ The personal grief that James felt at the death of this son was thus compounded by the revived factionalism with which he now had to contend.

So by invoking a prince who was a famous historical scourge of the French, it seems to me that this passage in Webster's elegy is no mere digression. The

${ }^{78}$ Quoted in Smuts, Court Culture, 26

79 Thomas Adams, The Deuills Banket [...] (London: Thomas Snodham for Ralph Mab, 1614), 324.

80 Ibid., 327.

${ }^{81}$ On the connections between Adams and Webster, see Emma Rhatigan, 'Reading the White Devil in Thomas Adams and John Webster', in Adrian Streete (ed.), Early Modern Drama and the Bible: Contexts and Readings, 1570-1625 (Basingstoke: Palgrave, 2012), 176-94.

82 'Randououe' = 'rendezvous'. Thomas Scott, Christs Politician, And Salomons Puritan [...] (London: Edward Griffin and Francis Constable, 1616), sigs. B1v, 4, 24.

${ }^{83}$ See Bellany, The Politics, 205.

${ }^{84}$ Peter McCullough, Sermons at Court: Politics and Religion in Elizabethan and Jacobean Preaching (Cambridge: Cambridge University Press, 1998), 176. For politics and the sermon more generally, see 169-93. 
political use of anti-French rhetoric aligns him with those who feared the possibility of a French Roman Catholic match for the new heir. It may also encode a subtle critique of Carr's pro-French policy. It was well known in England that, in the aftermath of Henri IV's death, the Regent Marie De Medici was struggling to hold the country together, fearful as she was of a Protestant uprising. There was considerable doubt that France was in any fit position to be negotiating large marriage dowries. But despite this, and despite the fact that both major court factions opposed a French match, at the end of 1613/ start of 1614, when The Duchess of Malfi was likely first performed, this seemed to be the most likely outcome. Indeed, in January 1614 'ambassador Thomas Edmondes returned to England with a French proposal in hand. ${ }^{, 85}$ The only way to prevent the king pursuing a French marriage, supported by Carr, was to press for a recall of Parliament and for that institution to grant the king his subsidy, thus bypassing the need for what many saw as an unpropitious union.

A second important context is patronage. Webster's elegy and play are both written in the aftermath of Cecil's death in 1612 when patronage networks are unstable. During this period Webster and Chapman turn to Carr as a patron. In his elegy, Webster calls Chapman, a writer strongly associated with Henry's court and ideology, his 'frend'. 86 Carr would have known that Chapman was Henry's man. Is Webster indirectly suggesting that Carr might accommodate Henry's former client? In The Duchess of Malfi, the man that the duchess goes on to secretly marry, Antonio, opens the play with a speech in praise of the French court and political system (I.i.1-22). Given the political context outlined here, perhaps this pro-French passage would have been viewed sceptically by audiences. Yet Antonio speaks of a 'judicious King' who purges his court of 'Of flatt'ring sycophants, of dissolute,/ And infamous persons' (I.i.5-8). Read in the context of the elegies, this passage may have brought to mind the French king Henri IV, murdered in 1610, and whom Henry idolized. More prosaically, it may also have invoked the sober, godly court of the dead prince where merit and ability rather than flattery were rewarded. 'France' is open to multiple interpretations during this contested period. This fluidity is reflected in these possible interpretations of Webster's elegy and play.

Patronage is also a central thematic concern in The Duchess of Malfi. The military man Bosola resents having to rely upon the cardinal and his brother Ferdinand. They 'are like plum trees that grow crooked over standing pools: they are rich and o'erladen with fruit, but none but crows, pies, and caterpillars feed on them. Could I be one of their flattering panders, I would hang on their ears like a horse leech till I were full, and then drop off' (I.i.49-54). We might think here of Christopher Brooke's soldier 'embast in these degenerate times'. Parasitic and animalistic imagery builds a relationship of mutual disgust and

85 Bellany, The Politics, 62.

86 Webster, A Monvmental Colvmne, 268. 
loathing that we often see in anti-Catholic writing of this period. ${ }^{87}$ Moreover, the relationship described here inverts the way in which the elegists for Prince Henry commonly describe his patronage. Webster himself writes:

He was not like the mad and thriftlesse Vine,

That spendeth all her blushes at one time:

But, like the Orange tree, his fruits he bore;

Some gather'd, he had greene, and blossomes store.

Wee hop't much of him, till death made hope err. ${ }^{88}$

The ecologically communal relationship described here is halted by death and, as in Bosola's lines, a sense of mutability pervades. Bosola shows what happens when godly patrons are gone, and when the militant-minded are forced to find patronage in more compromised, pro-Catholic circumstances. In both these examples, it is likely that Webster has that biblical locus classicus of mutability in mind, the opening chapter of Joel:

That which is left of the palmer worme, hath the grasshopper eaten, and the residue of the grasshopper hath the canker worme eaten, and the residue of the canker worme hath the cater pillar eaten [...] weepe and howl ye drinkers of wine, because of the new wine, for it shall be pulled from your mouth [...] The vine is dried vp, and the figtree is decayed: the pomegranate tree and the palme tree, and the apple tree, euen all the trees of the fielde are withered: surely the ioy is withered away from the sonnes of men (Joel 1: 1-12).

Any sustenance that Bosola receives from his new patrons is likely to be corrupt. As he asks: 'What creature ever fed worse than hoping Tantalus' (I.i.56-57)? References to Tantalus are also commonplace in elegies for Henry and are often linked to a biblical imperative to punish sin. Thomas Heywood asks 'Is it because we breake the Gods decree,/ That Tantalus we are punisht like to thee,' and George Wither notes that 'We had but of his excellence a sight,/ To make our longings like to Tantalus. ${ }^{89}$ It is in Bosola that the drama comes closest to what Walter Benjamin calls the Trauerspiel, a kind of mourning play 'which is revealed under the gaze of the melancholy man'. ${ }^{90}$ This melancholy male grief without proper outlet makes Bosola susceptible to political corruption: 'want of action/ Breeds all black malcontents' (I.i.81).

\footnotetext{
${ }^{87}$ Animal imagery is a feature of court sermons from this period: e.g. Scot, Christs Politician, 7-8.

88 Webster, A Monvmental Colvmne, 43-47.

${ }^{89}$ Heywood's text was written in praise of Frederick and Elizabeth's marriage but, like most of these texts, it contains obsequies for Henry too. Thomas Heywood, A Marriage Triumph Solemnized [...] (London: N. Okes for Edward Marchant, 1613), sig. B2r. Wither, Prince Henries Obsequies, sig. C3v.

${ }^{90}$ Walter Benjamin, The Origin of German Tragic Drama, trans. John Osborne (London and New York: Verso, 2003), 139.
} 
In his lycanthropic madness, Ferdinand likens the cardinal, the doctor, and the courtiers to 'beasts for sacrifice' (V.ii.70), a reminder of the idolaters of the Old Testament who refuse to observe the new covenant. ${ }^{91}$ The stain of idolatry, seen in the elegies, is redoubled for these Roman Catholic politiques. Antonio dies warning his son to 'fly the courts of princes' (V.v.71), Ferdinand by invoking the 'dust' (V.iv.71) which, as Job 34: 15 reminds us, all return to, and the cardinal by desiring not to be elegized, to be 'never thought of' (V.v.86). All this can be seen as a rejection of the elegiac mode. Indeed Bosola's last words are a kind of anti-elegy:

Oh, I am gone.
We are only like dead walls or vaulted graves
That, ruined, yields no echo. Fare you well.
It may be pain but no harm to me to die
In so good a quarrel. Oh, this gloomy world -
In what a shadow or deep pit of darkness
Doth, womanish and fearful, mankind live!
Let worthy minds ne'er stagger in distrust
To suffer death or shame for what is just.
Mine is another voyage. (V.v.95-104)

Unlike the echoes that commemorate the duchess in Act Five, scene three, there is no echo from these ruined 'dead walls, or vaulted graves'. ${ }^{92}$ The typological connection between Old and New Testament is important here. God promises the Israelites transcendence in Ezekiel - 'I will open your graues, and cause you to come vp out of your sepulchres, and bring you into the land of Israel' (Ezekiel 37: 12). In Matthew, Jesus promises the opposite, condemning the 'Scribes and Pharises, hypocrites: for ye are like vnto whited tombes, which appeare beautifull outward, but are within full of dead mens bones, and all filthinesse' (Matthew 23: 27). Bosola may rail against 'womanish' mankind that lives in a 'gloomy world'. Yet for all his misogynistic attempts to displace blame, he dies a murderous hypocrite who will not be memorialized. If he does emblematize the political and religious grief felt by many militants in the wake of Prince Henry's death then it is a savage depiction indeed.

Nevertheless, the play does not, as Benjamin says of the Trauerspiel more generally, enact 'the total disappearance of eschatology', nor of prophecy. ${ }^{93}$

\footnotetext{
${ }^{91}$ See in particular Moses' difficulties with Jews in Exodus, Chapters 30 to 40. See also Leviticus 11. On the cultural significance of lycanthropy, see Brett D. Hirsch, 'An Italian Werewolf in London: Lycanthropy and The Duchess of Malfi', Early Modern Literary Studies 11 (2005).

${ }^{92}$ The echo is a commonplace in pastoral poetry; see Kay, Melodious Tears, 175, and the story of Echo in Book Three of Ovid's Metamorphoses (8 AD); Ovid, Metamorphoses, trans. Denis Raeburn (London: Penguin, 2004), 109-116.

93 Benjamin, The Origin, 81. On the duchess and the prophetic mode, compare her speech at IV.ii.24-7 ('Th' heaven o'er my head seems made of molten brass;/ The earth of flaming sulphur, yet I am not mad./ I am acquainted with sad misery,/ As the tanned galley slave is with his oar') with Deuteronomy 28: 23 (And thine heauen that is ouer thine head, shallbe as brasse, and the earth that is vnder thee, iron').
} 
Delio says that those surviving should 'make noble use/ Of this great ruin' (V.v.108-09), a double-edged comment. Significantly, he is 'arm'd' as he points to the Duchess of Malfi's surviving son, enjoining the other courtiers to 'join all our force/ To establish this young hopeful gentleman/ In's mother's right' (V.v.107-11). The implication is striking. Aughterson argues that this moment offers an 'elegiac reminder of the iconic significance of the dead Prince Henry'. ${ }^{94}$ Her stress on the radical critique of masculinity found in Webster's drama is persuasive, but it fails to address the elegists' point that masculine energy needs to be directed somewhere. ${ }^{95}$ I think that the play's biblical language points us in a different direction. Political right can be re-established and protected through military arms and a 'force' that serves 'truth' (V.v.109; 117) and the surviving heir. We might be reminded of the way in which militant elegists like Wither had turned their attention to the new heir, Charles. Indeed, Webster quotes from Wither's Prince Henry's Obsequies in the Echo scene in Act Five. ${ }^{96}$ The play also concludes with a prophecy. As the final couplet puts it: 'Integrity of life is fame's best friend,/ Which nobly beyond death shall crown the end.' (V.v.119-20). In a play obsessed with the question of political and religious integrity, the power of elegy, prophecy, and the memory of the dead, these lines suggest that while personal honour is crucial, 'fame' is less important than the 'crown' received 'beyond death'. The words of Revelation 2: 10 explain the prophetic allusion at the end of the play: 'Feare none of those things, which thou shalt suffer: behold, it shall come to passe, that the deuill shall cast some of you in prison, that yee may be tried, and ye shall haue tribulation ten days: be thou faithfull vnto the death, and I will giue thee the crowne of life.' Even if The Duchess of Malfi is largely a study in elegiac futility, we should not discount the gleam of apocalyptic transcendence that concludes the play. For writers like Webster who had some sympathy with militant Protestant ideology, the existence of an heir, however young and inexperienced, at least kept the glimmer alive.

University of Glasgow

\footnotetext{
94 Aughterson, 'Roaring Boys', 60.

95 Ferdinand's courtiers dissuade him from martial activity in I.ii.8-34.

${ }^{96}$ See John Webster, The Duchess of Malfi, ed. John Russell Brown (London: Methuen, 1964), xxxv, and Neill, Issues of Death, 337.
} 